Spoerl / The Levantine Review Volume 2 Number 1 (Spring 2013)

\title{
MUHAMMAD AND THE JEWS ACCORDING TO IBN ISHAQ
}

\author{
Joseph Spoerl*
}

\begin{abstract}
This paper examines the phenomenon of anti-Semitism in the Muslim world, shedding light on one component of the Islamic tradition, namely, the earliest extant biography of the Prophet Muhammad, the Sirat Rasul Allah, or The Life of the Prophet of God by Ibn Ishaq (d. 767 CE.)
\end{abstract}

\section{INTRODUCTION}

A number of scholars have chronicled the intensification and spread of anti-Semitism in large parts of the Muslim world over the past 80 years or so, some of them-including Andrew Bostom, ${ }^{1}$ Robert Wistrich, ${ }^{2}$ Matthias Kuentzel, ${ }^{3}$ Klaus Gensicke, ${ }^{4}$ Meir Litvak, ${ }^{5}$

\footnotetext{
${ }^{1}$ Andrew Bostom, ed. The Legacy of Islamic Antisemitism (Amherst, NY: Prometheus Books, 2008).

2 Robert Wistrich, Antisemitism: The Longest Hatred (New York: Shocken Books, 1991), 195-267; Muslim Anti-Semitism: A Clear and Present Danger (N.P.: The American Jewish Committee, 2002) http://www.ajc.org/atf/cf/\%7B42D75369-D582-4380-8395D25925B85EAF\%7D/WistrichAntisemitism.pdf; A Lethal Obsession: Anti-Semitism from Antiquity to the Global Jihad (New York: Random House, 2010). The second of these works has just been published in an updated German translation: Robert Wistrich, Muslimischer Antisemitismus: Eine Aktuelle Gefahr (Berlin: Edition Critic, 2011); see review by Manfred Gerstenfeld at http://spme.net/articles/8687/3/11/Muslim-Hard-Core-anti-SemitismComparable-to-that-of-the-Nazis.html.

${ }^{3}$ Matthias Küntzel, Jihad and Jew-Hatred: Islamism, Nazism and the Roots of 9/11 (New York: Telos Press Publishing, 2007).

${ }^{4}$ Klaus Gensicke, The Mufti of Jerusalem and the Nazis: The Berlin Years, trans. Alexander Fraser Gunn (London and Portland, OR: Vallentine Mitchell, 2011). [This book is a translation and updated revision of Klaus Gensicke, Der Mufti von Jerusalem und die Nationalsozialisten: Eine Politische Biographie Amin el-Husseinis (Darmstadt: Wissenschatliche Buchgesellschaft, 2007).]

${ }^{5}$ Meir Litvak, "The Anti-Semitism of Hamas," Palestine-Israel Journal of Politics, Economics, and Culture 12 (2005), http://www.pij.org/details.php?id=345; Meir Litvak and Esther Webman, From Empathy to Denial: Arab Responses to the Holocaust (New York: Columbia University Press, 2009).
} 


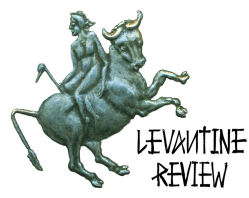

Bernard Lewis, ${ }^{6}$ Yehoshafat Harkabi, ${ }^{7}$ David Patterson, ${ }^{8}$ Bat Ye'or, ${ }^{9}$ Mark Durie, ${ }^{10}$ Itamar Marcus, ${ }^{11}$ Neil J. Kressel, ${ }^{12}$ and Jeffrey Herf ${ }^{13}$ - tracing its roots further back in Islamic history. In addition, the media analysts of the Middle East Media Research Institute and Palestinian Media Watch have assembled a massive and growing body of anti-Semitic material from Muslim sources. ${ }^{14}$ Moreover, recent polling data from the Pew Research Center shows very high levels of anti-Jewish prejudice across the Muslim world. ${ }^{15}$ Muslim anti-Semites have certainly borrowed freely from Western anti-Semitic works such as the Protocols of the Elders of Zion, ${ }^{16}$ but, as the aforementioned scholars show, they have also mined the Islamic tradition itself for raw materials with which to craft anti-Semitic propaganda. A full understanding of Islamic anti-Semitism thus requires not only a survey of current events, but an understanding of the Islamic tradition and its treatment of Jews.

This article will examine just one important component of the Islamic tradition in this regard, namely, the earliest extant biography or sira of Muhammad, the Sirat Rasul Allah or The Life of the Prophet of God by Muhammad Ibn Ishaq Ibn Yasar, generally known as Ibn

\section{${ }^{6}$ Bernard Lewis, Semites and Anti-Semites (New York and London: W.W. Norton and Company, 1999); The Jews of Islam (Princeton: Princeton University Press, 1984). \\ 7 Yehoshafat Harkabi, Arab Attitudes to Israel, trans. Misha Louvish (Jerusalem: Israel Universities Press, 1972). \\ 8 David Patterson, A Genealogy of Evil: Anti-Semitism from Nazism to Islamic Jihad} (Cambridge: Cambridge University Press, 2011).

${ }^{9}$ Bat Ye'or, The Dhimmi: Jews and Christians Under Islam, trans. David Maisel, Paul Fenton, and David Littman (Rutherford NJ: Fairleigh Dickinson University Press, 1985), Islam and Dhimmitude: Where Civilizations Collide, trans. Miriam Kochan and David Littman (Madison NJ: Fairleigh Dickinson University Press, 2002).

10 Mark Durie, The Third Choice: Islam, Dhimmitude, and Freedom (N.P.: Deror Books, 2010).

11 Itamar Marcus and Nan Jacques Zilberdik, Deception: Betraying the Peace Process (Jerusalem: Palestinian Media Watch, 2011).

12 Neil J. Kressel, "The Sons of Apes and Pigs:" Muslim Anti-Semitism and the Conspiracy of Silence (Washington DC: Potomac Books, 2012).

13 Jeffrey Herf, Nazi Propaganda for the Arab World (New Haven and London: Yale University Press, 2009).

${ }^{14}$ Middle East Media Research Institute: www.memri.org; Palestinian Media Watch: www.palwatch.org.

15 For recent polling data demonstrating extremely high levels of anti-Jewish bias in Muslim countries, see the Pew Research Center Global Attitudes Project Report, July 21, 2011, "Muslim-Western Tensions Persist," especially pp. 42-3; http://www.pewglobal.org/files/2011/07/Pew-Global-Attitudes-Muslim-WesternRelations-FINAL-FOR-PRINT-July-21-2011.pdf

${ }^{16}$ Menahem Milson, "A European Plot on the Arab Stage: The Protocols of the Elders of Zion in the Arab Media," Middle East Media Research Institute, May 20, 2011, www.memri.org. 


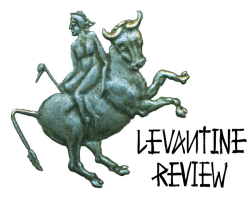

Ishaq, who died in Baghdad roughly in $767 \mathrm{CE}$ (or $151 \mathrm{AH}$ ). Ibn Ishaq's sira is passed down to us in an abridged and annotated recension by a later scholar, Ibn Hisham (d. c. 833 CE), although it is possible to undo some of Ibn Hisham's abridgement since other historians such as al-Tabari quote large portions of the earlier unabridged version in their writings. ${ }^{17}$ Ibn Ishaq's biography forms the basis of virtually all later biographies of Muhammad in the Islamic tradition. ${ }^{18}$ It is, in F. E. Peters' words, "the classical and canonical biography of Muhammad." 19 There is a wide variety of opinion among scholars of early Islam as to whether Ibn Ishaq's sira is reliable. ${ }^{20}$ I will abstain altogether from taking a position in this debate and focus entirely on the contents of the book, since its impact on the Islamic tradition is indisputable even if its historical accuracy is not. ${ }^{21}$

17 Alfred Guillaume, The Life of Muhammad: A Translation of Ibn Ishaq's Sirat Rasul Allah (Oxford and Karachi: Oxford University Press, 1955), p. xxx-xxxi.

18 Francis Peters observes, "all the earliest surviving versions of Muhammad's life rely heavily on Ibn Ishaq's original Sira." F. E. Peters, "The Quest of the Historical Muhammad," International Journal of Middle East Studies, 23 (1991), p. 304.

${ }^{19}$ F.E. Peters, Muhammad and the Origins of Islam (Albany: State University of New York Press, 1994), p. 49.

20 See, for example, F. E. Peters, "The Quest of the Historical Muhammad," International Journal of Middle East Studies, 23 (1991), pp. 291-315, reprinted in F.E. Peters, Muhammad and the Origins of Islam, pp. 257-268, and Fred M. Donner, Muhammad and the Believers: At the Origins of Islam (Cambridge, MA and London, UK: The Belknap Press of Harvard University Press, 2010), pp. 50-56 and 242-244. For a more trusting view of Ibn Ishaq's reliability, see W. Montgomery Watt, "The Reliability of Ibn Ishaq's Sources," in Watt, Early Islam: Collected Articles (Edinburgh: Edinburgh University Press, 1990), pp. 13-23. A very skeptical view of Ibn Ishaq is that of Patricia Crone and Michael Cook, Hagarism: The Making of the Muslim World (Cambridge: Cambridge University Press, 1980). A highly accessible summary of the scholarship in this area is Robert Spencer, Did Muhammad Exist? An Inquiry Into Islam's Obscure Origins (Wilmington, DE: ISI Books, 2012).

${ }^{21}$ In the words of M. J. Kister: "The narratives of the Sirah have to be carefully and meticulously sifted in order to get at the kernel of historically valid information, which is in fact meager and scanty. But the value of this information for the scrutiny of the social, political, moral, and literary ideas of the Muslim community cannot be overestimated; during the centuries, since Muslim society came into existence, the revered personality of the Prophet served as an ideal to be followed and emulated." M. J. Kister, "The Sirah Literature," in ed. A. F. L. Beeston et al., Arabic Literature to the End of the Umayyad Period (The Cambridge History of Arabic Literature) (Cambridge: Cambridge University Press, 1983), pp. 352-367. 


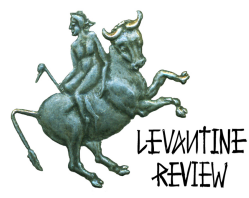

I will be using Alfred Guillaume's English translation of Ibn Ishaq, published by Oxford University Press, ${ }^{22}$ quoting passages in roughly the order of Ibn Ishaq's narrative. (In what follows, page numbers in the text in parentheses refer to Guillaume's translation; all other references are given in footnotes.) My main concern will be with the ideological conflict between Muhammad and the Jews, and only secondarily with the military and political aspects of this conflict. My thesis is that the root of the conflict between Muhammad and the Jews, as depicted by Ibn Ishaq, was Muhammad's insistence, and the Jews' denial, that the Jewish scriptures unambiguously identify Muhammad as the final prophet for whom the Jews have been waiting for centuries. This theological conflict underlay the political and military dimensions of the conflict and led Muhammad to unleash an intense campaign of anti-Jewish propaganda that spawned anti-Jewish stereotypes that endure even today in the Muslim world. ${ }^{23}$ This paper will provide evidence supporting Neil J. Kressel's assertion that "far from being a byproduct of the Arab-Israeli conflict, Jew-hatred has roots in the long history and complex theology of Islam."24

\section{LIFE OF MUHAMMAD UP TO THE HIJRA (570-622)}

Ibn Ishaq sets the stage for Muhammad's relations with the Jews early in the sira with his account of a trip to Syria on which the very young Muhammad accompanied his uncle, Abu Talib. "When the caravan reached Busra in Syria, there was a monk there in his cell by the

${ }^{22}$ Alfred Guillaume, The Life of Muhammad: A Translation of Ibn Ishaq's Sirat Rasul Allah (Oxford and Karachi: Oxford University Press, 1955). Ibn Ishaq's life of Muhammad was in fact embedded in an ambitious "universal history" that covered the history of the world from the creation up to Ibn Ishaq's own time (the Abbasid caliphate). For a reconstruction of Ibn Ishaq's history covering the period before the time of Muhammad (that is, the portion leading up to where Guillaume's work begins), see Gordon Darnell Newby, The Making of the Last Prophet: A Reconstruction of the Earliest Biography of Muhammad (Columbia, SC: The University of South Carolina Press, 1989).

23 Fred M. Donner has argued that Muhammad led an ecumenical movement that welcomed Jews and unitarian Christians as well as ex-polytheist converts to monotheism. Donner maintains that Islam did not emerge as a distinct religious confession until several generations after the death of Muhammad and that classical Islamic writers of later centuries anachronistically interpreted the Koran, and re-told the life of Muhammad, so as to make it seem that Muhammad led a movement of pure Muslims who professed the classical Islam of later centuries. Donner would thus presumably dismiss Ibn Ishaq's sira as a product of this later anachronistic mindset and therefore minimize the extreme and even violent tensions between Muhammad and the Jews as recounted by Ibn Ishaq. See Fred M. Donner, "From Believers to Muslims: Confessional Self-Identity in the Early Islamic Community" Al-Abhath 50-51 (2002-2003), pp. 9-53. If Donner is right, it would not affect the thesis of the present paper, which focuses entirely on the contents of Ibn Ishaq's sira while prescinding from the question of its historical accuracy. ${ }^{24}$ Neil J. Kressel, "The Sons of Pigs and Apes," p. 1. 


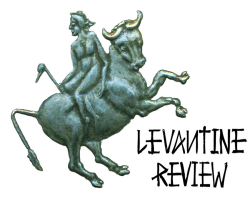

name of Bahira" (p. 79). After consulting certain unnamed Christian books and locating the seal of prophethood on Muhammad's back, Bahira identifies Muhammad as a prophet and then warns Abu Talib: "Take your nephew back to his country and guard him carefully against the Jews, for by Allah! If they see him and know about him what I know, they will do him evil..." (p. 81). Indeed, we are told, several "people of the scriptures" noticed in Muhammad what Bahira had noticed, and "they tried to get at him, but Bahira kept them away and reminded them of God and the mention of the description of him which they would find in the sacred books... He gave them no peace until they recognized the truth of what he said and left him and went away" (p. 81). Ibn Ishaq tells us that "Jewish rabbis, Christian monks, and Arab soothsayers had spoken about the apostle of God before his mission when his time drew near. As to the rabbis and monks, it was about his description and the description of his time which they found in their scriptures and what their prophets had enjoined upon them" (p. 90). With only one exception, Ibn Ishaq gives no specific citations of texts allegedly foretelling Muhammad's coming. The one exception is his reference to the Gospel of John 15:23ff, the verses referring to the coming of the Comforter or paraclete or the spirit of truth (which Christians interpret as referring to the sending of the Holy Spirit) (pp. 103-4).

Ibn Ishaq mentions several specific accounts of Jews in Arabia right before the time of Muhammad predicting the coming of a prophet with Muhammad's attributes, only to reject Muhammad out of "wickedness and envy" when they actually encountered him (pp. 93-95). One of these accounts quotes the Koran 2:89: "And when a book from God came to them confirming what they already had [....] when what they knew came to them, they disbelieved it. The curse of God is on the unbelievers" (p. 93).

After Muhammad began to preach Islam publicly in 613 (the revelations having begun in 610), Ibn Ishaq tells us of a delegation of some twenty Christians from Abyssinia (or Najran) who came to Mecca to investigate his claims. "When they had asked all the questions they wished the apostle invited them to come to God and read the Quran to them. When they heard the Quran their eyes flowed with tears, and they accepted God's [note omitted] call, believed in him, and declared his truth. They recognized in him the things which had been said of him in their scriptures" (p. 179; cf. pp. 271, 277). This passage shows that Muhammad saw the Christian scriptures in the same way he saw the Jewish scriptures, namely, as plainly foretelling his coming as a prophet. ${ }^{25}$ However, the Jews were

\footnotetext{
${ }^{25}$ Ibn Ishaq (somewhat tentatively) links this incident in Muhammad's life to a specific verse in the Koran, 28:51: "Those to whom We gave the Scriptures before this believe in it. When it is recited to them they say: 'We believe in it; it is the truth from our Lord. We submitted to Him long before it came."' (p. 179). The moral of the story is that Christians (like Jews) who are faithful to their own scriptures will convert to Islam as soon as it is presented to them.
} 


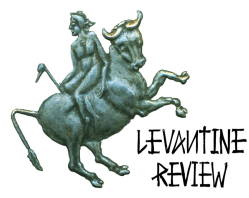

apparently far more numerous in the Hijaz than the Christians, so Ibn Ishaq has much more to say about them, especially after the hijra. ${ }^{26}$

These passages from the first two hundred pages of Ibn Ishaq's sira, covering Muhammad's life up to the hijra, convey the following themes: the sacred books of the Jews and Christians plainly describe Muhammad and foretell his coming, with the clear implication that only dishonest and wicked people of the book would deny his prophethood. ${ }^{27}$

\section{LIFE OF MUHAMMAD AFTER THE HIJRA (622-632)}

After the Hijra in the year $622 \mathrm{CE}$, Ibn Ishaq initially paints a remarkably peaceful scenario: Muhammad enters a covenant with the Medinans and the Jews (the so-called "Constitution of Medina"), described as "a friendly agreement with the Jews" establishing them in their religion and their property (p. 231). The Muslims, for their part, settle down to practice their faith with a freedom unknown previously in Mecca: "Prayer was instituted, the alms tax and fasting were prescribed, legal punishments fixed, the forbidden and permitted prescribed, and Islam took up its abode with them" (p. 235).

However, this peaceful idyll is quickly shattered by two groups, the Jews and the hypocrites:

About this time the Jewish rabbis showed hostility to the apostle in envy, hatred, and malice, because God had chosen His apostle from the Arabs. They were joined by men from al-Aus and al-Khazraj who had obstinately clung to their heathen religion. They were hypocrites, clinging to the polytheism of their fathers denying the resurrection; yet when Islam appeared and their people flocked to it they were compelled to pretend to accept it to save their lives. But in secret they were hypocrites whose inclination was towards the Jews because they considered the apostle a liar and strove against Islam. (p. 239)

Ibn Ishaq adds: "It was the Jewish rabbis who used to annoy the apostle with questions and introduce confusion, so as to confound the truth with falsity" (p. 239). He then gives a lengthy and detailed list of Muhammad's "Jewish adversaries" (pp. 239-240). After presenting this list, he says: "These were the Jewish rabbis, the rancorous opponents of the apostle [...,] the men who asked questions, and stirred up trouble against Islam to try to

${ }^{26}$ Ibn Ishaq even asserts that the polytheists of Mecca knew that Muhammad was telling them the truth, "but envy prevented them from admitting his truth" (pp. 140-1). So Jews, Christians, and polytheists alike are portrayed as dishonest when they reject Muhammad's message: the only honest non-Muslims are the ones who convert to Islam.

27 The Koran asserts this quite explicitly, referring to Muhammad as "the Apostle -- the unlettered prophet - whom they shall find described to them in the Torah and the Gospel" $(7: 157)$. 


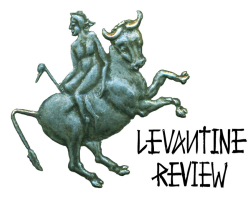

extinguish it, except for Abdullah b. Sallam and Mukhayriq [note omitted]" (p. 240). ${ }^{28}$ Since Abdullah b. Sallam and Mukhayrik were converts to Islam (pp. 239-40), the message is clear: the only good rabbis are the ones who convert to Islam.

Ibn Ishaq recounts in detail the story of Abdullah bin Sallam's conversion to Islam, quoting Abdullah as follows: "When I heard about the apostle I knew by his description, name, and the time at which he appeared that he was the one we were waiting for, and I rejoiced greatly thereat, though I kept silent about it until the apostle came to Medina" (p. 240). Abdullah kept his conversion a secret and went to Muhammad and said, "The Jews are a nation of liars and I wish you would take me into one of your houses and hide me from them. Then ask them about me so that they may tell you the position I hold among them before they know that I have become a Muslim." Muhammad did just this, and the Jews confirmed that Abdullah was their respected leader and rabbi. Abdullah then jumped from his hiding place and exhorted the Jews as follows:

O Jews, fear God and accept what He has sent you. For by God you know that he is the apostle of God. You will find him described in your Torah and even named. I testify that he is the apostle of God, I believe in him, I hold him to be true, and I acknowledge him.' They accused me of lying and reviled me. Then I reminded the apostle that I had said they would do this, for they were a treacherous, lying, and evil people. (p. 241)

The allegation that the Jews lie about and distort the contents of their scriptures is repeated over and over again in Ibn Ishaq. In his lengthy commentary on Sura 2 of the Koran, Ibn Ishaq tells us that "the first hundred verses of the Sura of the Cow came down in

${ }^{28}$ Maxime Rodinson makes an astute observation about the Jews of Medina: "Even if they had been well disposed towards the new movement, it was not easy for them to sanction what in their view were the incoherent ramblings of an illiterate, nor was it easy to avoid pointing out the way in which the Koran distorted the Old Testament stories and the errors and anachronisms of which it was full." Maxime Rodinson, Muhammad, trans. Anne Carter (New York: The New Press, 1980), p. 161. W. Montgomery Watt makes a similar point: after the migration to Medina, "The Jews...became increasingly hostile, and used their knowledge of the Old Testament to criticize Muhammad's claim that the Qur'an was the speech of God. In a largely illiterate environment it was easy for them to assert and appear to prove that the Qur'an was mistaken in various matters mentioned in the Old Testament. And the conclusion of the argument, of course, was that the Qur'an was not the speech of God and that therefore Muhammad was not a prophet. In view of the gravity of this matter it must have been one of Muhammad's chief preoccupations during the early months." W. Montgomery Watt, Muhammad: Prophet and Statesman (Oxford: Oxford University Press, 1961), p. 99. Indeed, Ibn Ishaq and Sura 2 of the Koran make it abundantly clear that this was a major preoccupation of Muhammad after the hijra. Cf. Tor Andrae, Mohammed: The Man and His Faith, trans. Theophil Menzel (New York: Scribner, 1936), p. 192. 


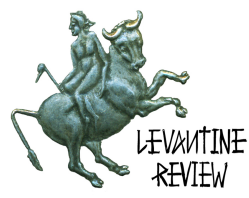

reference to these Jewish rabbis and the hypocrites of Aus and Khazraj..." (p. 247). God's message in Sura 2 includes the following admonitions aimed at the Jews:

- "...do not conceal the knowledge which you have about My apostle and what he has brought when you will find it with you in what you know of the books which are in your hands." (p. 250)

- "...you contradict what you know to be in My book." (p. 250)

- "...there is a party of them who listen to the word of God then change it after they understand it, doing so knowingly." (p. 251)

- "... a party of them changed the commandments they had been given..." (p. 251)

- "'And when there comes to them what they know they deny it. God's curse is on the unbelievers. Wretched is that for which they sell themselves in disbelieving in what God has sent down, grudging that God should send down of his bounty upon whom He will of His servants,' i.e. that He should have given it to one who was not of them. 'They have incurred anger upon anger and for the unbelievers there is a shameful punishment.' [note omitted] The double anger is His anger at what they have disregarded of the Torah which they had and His anger at their disbelieving in this prophet whom God had sent to them." (p. 254)

- "...they know about thee [Muhammad] by the knowledge which they have and deny it." (p. 254) 29

An interesting aspect of Ibn Ishaq's commentary on Sura 2 is his treatment of the famous verse 256, which says "there shall be no compulsion in religion." According to Ibn Ishaq this verse was cited by Muhammad in a letter to the Jews of Khaybar as follows: "...Do you find in what He [God] has sent down to you that you should believe in Muhammad? If you do not find that in your scripture then there is no compulsion upon you. 'The right path has become plainly distinguished from error' [note omitted] so I call you to God and His prophet" (p. 256). This is the only allusion to verse 2:256 in the entire sira, and it is significant that the precept "there shall be no compulsion in religion" is only stated in a conditional form: "If you do not find in your scriptures the foretelling of Muhammad's coming as a prophet, then there is no compulsion upon you." However, in the very same paragraph, Muhammad asserts that the condition is not fulfilled. As we have seen, the entire sira repeatedly denies that the condition has been fulfilled, insisting that the Jews know that their scriptures foretell Muhammad's coming and then lie about it. Indeed, Ibn Ishaq's life of Muhammad is filled with examples of religious compulsion sanctioned by

${ }^{29}$ Koran verses that accuse Jews or "people of the book" of distorting or lying about their scriptures include the following: 2:59, 2:75, 2:79, 2:89, 2:101, 2:140, 2:146, 2:159, 2:160, 2:174, 2:211, 3:70-71, 3:78, 3:187, 5:12-15, 5:41, 6:91, 13:36. (See Appendix for text.) All of these but one (6:91) come from Medinan suras, consistent with Ibn Ishaq's narrative, according to which Muhammad had relatively little contact with Jews in Mecca before the hijra.

ISSN: 2164-6678 


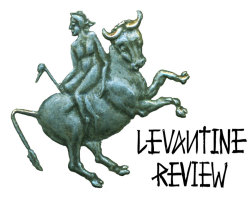

Muhammad..$^{30}$ Near the end of the sira, Ibn Ishaq quotes Abu Bakr as summing up Muhammad's career as follows: "God sent Muhammad with this religion and he strove for it until men accepted it voluntarily or by force" (pp. 668-9). Ibn Ishaq thus lends support to the classical Islamic scholars who argue that verse 2:256 was abrogated by verses revealed later, especially the verses of Sura 9.31

Ibn Ishaq portrays Muhammad himself as repeatedly telling the Jews that his coming as a prophet is plainly foretold in the Jewish scriptures. After the Muslim victory over the pagan Quraysh at the battle of Badr, Muhammad assembled the Jews of the Banu Qaynuqa in the marketplace in Medina and addressed them as follows: "O Jews, beware lest God bring upon you the vengeance that he brought upon Quraysh and become Muslims. You know that I am a prophet who has been sent - you will find that in your scriptures and in God's covenant with you" (p. 363; cf. also pp. 248, 249, 250, 252, 257, where acceptance of Muhammad is said to be a part of the Jews' covenant with God). Muhammad directed the same message to the Jews of Khaybar: "The apostle wrote to the Jews of Khaybar [...] God says to you, 0 scripture folk, and you will find it in your scripture, 'Muhammad is the apostle of God...'” (p. 256). One catches occasional glimpses of the bafflement that Muhammad's assertions elicited from Jewish interlocutors: "'He has not brought us anything we recognize and he is not the one we spoke of to you.'” "'No covenant was ever made with us about Muhammad."' "'O Muhammad, you have not brought us anything we recognize...'” (all on p. 257). "'Is it true, Muhammad, that what you have brought is the truth from God? For our part, we cannot see that it is arranged as the Torah is.' He [Muhammad] answered, 'You know quite well that it is from God; you will find it written in the Torah which you have.'” (p. 269; cf. p. 270).

Ibn Ishaq also portrays Muhammad's closest followers conveying the same message: Abu Bakr, upon entering a Jewish school, called upon the rabbi "to fear God and become a Muslim because he [the rabbi] knew that Muhammad was the apostle of God who had brought the truth from Him and that they would find it written in the Torah and the Gospel" (p. 263).

Some verses in the Koran that seemingly strike a conciliatory and tolerant tone regarding the Jews take on a very different meaning in Ibn Ishaq's gloss. Consider, for example, 3:113117: "They are not (all) alike: of the scripture folk there is an upright community who read God's verses in the night season prostrating themselves [note omitted]. They believe in God

30 See Joseph S. Spoerl, "Islam and War: Tradition vs. Modernity” Comparative Islamic Studies 4 (2008), pp. 181-212, esp. pp. 191-195.

31 David S. Powers, "The Exegetical Genre nasikh al-Qur'an wa mansukhuhu," in Andrew Rippin, ed., Approaches to the History of the Interpretation of the Qur'an (Oxford: Clarendon, 1988), pp. 117-138, and David Bukay, "Peace or Jihad? Abrogation in Islam," Middle East Quarterly, Fall 2007, pp. 3-11. 


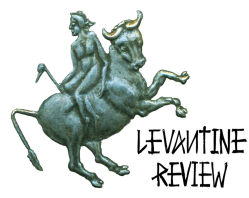

and the last day and enjoin good conduct and forbid evil and vie with one another in good works. Those are the righteous...." On Ibn Ishaq's interpretation, these verses refer only to a small group of Jews who had converted to Islam: Abdullah bin Sallam, Thalaba bin Saya, and Usayd bin Saya (p. 262). ${ }^{32}$ In other words, the message is that the only good Jews are those who convert to Islam. Ibn Ishaq's influence can be traced centuries later in one of the most respected commentaries on the Koran, the Tafsir of Ibn Kathir (1301-1373). Ibn Kathir writes of verses 3:113ff:

Muhammad bin Ishaq and others...said ; 'These Ayat [verses] were revealed about the clergy of the People of the Scriptures who embraced the faith. For instance, there is Abdullah bin Salam, Asad bin Ubayd, Thalabah bin Sayah, Usayd bin Sayah, and so forth. This Ayah [verse] means that those among the People of the Book whom Allah rebuked earlier [in 3:111] are not at all the same as those among them who embraced Islam. ${ }^{33}$

Sura 109 is another set of verses that seem to convey an attitude of religious tolerance: "Say, O disbelievers, I do not worship what you worship, and you do not worship what I worship [...] You have your religion, and I have mine." According to Ibn Ishaq, these verses were revealed in Mecca before the hijra when Muhammad was in a position of weakness and when he was under pressure to adopt a syncretistic compromise with the polytheists who were persecuting him. A group of polytheists came to Muhammad and made this proposal: "Muhammad, come let us worship what you worship, and you worship what we worship. [....] If what you worship is better than what we worship we will take a share in it, and if what we worship is better than what you worship, you can take a share of that" (p. 165). Ibn Ishaq makes it clear that Muhammad's response was an emphatic rejection of any compromise between strict monotheism and the polytheism of the Quraysh. Sura 109 is not an endorsement of religious tolerance, then, but a rejection of syncretism. Moreover, the revelation of 9:5 some years later in 631 would entail complete and total intolerance for any sort of polytheism in Arabia. ${ }^{34}$ Ibn Ishaq also places the revelation of Sura 109 in the context of the "Satanic verses," an episode that also led to an emphatic rejection of syncretism after a brief and mistaken flirtation with the idea by Muhammad (pp. 165-7). It

\footnotetext{
${ }^{32}$ In general the Koran is quite sparing in its praise of the "people of the book" and always counter-balances its tepid praise with much harsher criticism. Typical verses assert "Some are true believers, but most are evildoers" (3:110); "you will find them ever deceitful except for a few of them" (5:13); "People of the Book...most of you are evil-doers" (5:56); "There are some among them who are righteous men; but there are many among them who do nothing but evil" (5:66).

${ }^{33}$ Shaykh Safiur-Rahman Al-Mubarakpuri et al., eds., second edition, Tafsir Ibn Kathir (abridged) (Riyadh: Darussalam, 2003), Volume 2, p. 246.

${ }^{34}$ F.E. Peters, Muhammad and the Origins of Islam, p. 244, and Reuven Firestone, Jihad: The Origins of Holy War in Islam (Oxford: Oxford University Press, 1999), pp. 88-89.
} 


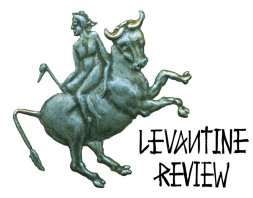

is also worth noting that Sura 109 is addressed only to polytheists, not to people of the book.

A key theme in Ibn Ishaq's depiction of the Jews is that they are chronic violators of their covenant with God. In one of the passages quoted above, Muhammad specifically links recognition of him as a prophet with fidelity to the Jewish covenant: "You know that I am a prophet who has been sent - you will find that in your scriptures and in God's covenant with you" (p. 363). The Koran 2:65 (and 5:60 and 7:166) alleges that God has punished past generations of Jews for their infidelity to the covenant (specifically, for violating the Sabbath) by transforming them into "detested apes," a claim echoed by Ibn Ishaq, who describes this bestial transformation as divine vengeance (pp. 250-1, 462). In his account of Muhammad's attack on the last of the Jewish tribes of Medina, the Banu Qurayza, Ibn Ishaq portrays Muhammad as addressing them as follows: "When the apostle approached their forts he said, 'You brothers of monkeys, has God disgraced you and brought His vengeance upon you?'” (p. 461). ${ }^{35}$ This was not a piece of gratuitous verbal abuse on Muhammad's part. In rejecting Muhammad's claim to be a prophet, the Jews of the Banu Qurayza were violating their own covenant as Jews, since (Muhammad thought) the Torah clearly named and foretold Muhammad as a prophet the Jews must accept. Like the Jews of the past who had broken their covenant and whom God had punished by transforming them into apes, the Jews of the Banu Qurayza were violating the covenant and thus were, figuratively speaking, "brothers of monkeys."

An important detail in Ibn Ishaq's treatment of the Jews has to do with the stoning of adulterers. According to Ibn Ishaq, the Jews of Muhammad's day had abandoned stoning for adultery. Their failure to stone adulterers is presented as yet another example of how they deny, ignore, and distort the contents of their own scriptures and violate their covenant. In one of the several versions of this story recounted by Ibn Ishaq, when presented with a man and woman caught in adultery, Muhammad asked for a Torah (to determine the divinely prescribed penalty for adultery). A rabbi held out a Torah, but with his hand covering over the verse of stoning. Abdullah bin Sallam, the rabbi who had converted to Islam, struck away the rabbi's hand, exclaiming "This, O prophet of God, is the verse of stoning which he refuses to read to you." Muhammad then says, "Woe to you Jews! What has induced you to abandon the judgment of God which you hold in your hands?' [...]

35 Ibn Ishaq's treatment of the Banu Qurayza episode has itself become the topic of scholarly controversy: see W.N. Arafat, "New Light on the Story of the Banu Qurayza and the Jews of Medina" Journal of the Royal Asiatic Society of Great Britain and Ireland (new series) 108 (1976), pp. 100-107, and (rebutting Arafat) M.J. Kister, "The Massacre of the Banu Qurayza: A Re-examination of a Tradition," Jerusalem Studies in Arabic and Islam 8 (1986), pp. 61-96. See also Gordon Darnell Newby, A History of the Jews of Arabia: From Ancient Times to Their Eclipse under Islam (Columbia, SC: The University of South Carolina Press, 1988), pp. 92-93. 


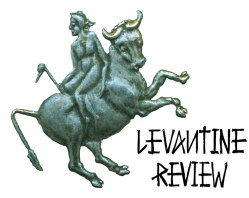

The apostle said: 'I am the first to revive the order of God and His book and to practice it.' They were duly stoned [...]" (p. 267). In another version of the same story in Ibn Ishaq, we are told that "the most learned man living in the Torah," the rabbi Abdullah bin Suriya, tells Muhammad privately, "Yes, [...] they [the Jews] know right well [...] that you are a prophet sent (by God) but they envy you" (p.267). The moral of the story is clear: The Jews cannot be trusted to give an honest account of the contents of their own holy books, either when it comes to the punishment for adultery, or the foretelling of Muhammad's coming as a prophet.

It is interesting to contrast the sira (and also the Koran) with the classical Islamic doctrine of revelation. According to classical Islamic doctrine, the Torah and Gospel were originally revealed by God to Moses and Jesus, respectively, but were corrupted by subsequent generations of Jews and Christians, so that in their current versions they are not authentic divine revelations (the doctrine of tahrif). ${ }^{36}$ However, neither the sira nor the Koran unambiguously affirms this doctrine. In the passages quoted above, we are told repeatedly that the Jews of Muhammad's time know that their scriptures foretell Muhammad's coming and lie in denying this. They are portrayed as dishonest, like the rabbis who denied that stoning is the revealed penalty for adultery, not as the unwitting victims of textual tampering by earlier generations of Jews..$^{37}$ Of course, many of the passages in the sira and Koran are inherently ambiguous: accusations that the Jews suppress or change the word of God could be construed as suggesting the classical Islamic doctrine of tahrif, but the overall picture drawn by Ibn Ishaq strongly suggests that Muhammad's accusation was that the Jews of his day were simply lying about what they knew to be in their holy books. ${ }^{38}$

36 "The obligation of belief [in Allah's inspired books] applies to the original revelations, not the various scriptures in the hands of non-Muslims, which are textually corrupt in their present form." Ahmad ibn Naqib al-Misri, The Reliance of the Traveller: A Classic Manual of Islamic Sacred Law, trans. Nuh Ha Mim Keller, rev. ed. (Beltsville, MD: 1994), p. 811. Camilla Adang explains that there is in fact a diversity of opinion in the Islamic tradition on this matter, some Muslim scholars affirming that Jews and Christians have actually corrupted the texts of their scriptures (tahrif al-nass) and others only stressing a difference of interpretation without suggesting the corruption of the text (tahrif al-ma'ani). Camila Adang, Muslim Writers on Judaism and the Hebrew Bible: From Ibn Rabban to Ibn Hazm (Leiden: E.J. Brill, 1996), pp. 223-248.

${ }^{37}$ In contrast, Ibn Hazm (ca. 994-1064) does portray the Jews as "unwitting victims of a deceitful or unwitting forbear." This, however, does not prevent him from subjecting the Jews to the most offensively vituperative stereotyping: Theodore Pulcini, Exegesis as Polemical Discourse: Ibn Hazm on Jewish and Christian Scriptures (Atlanta: The American Academy of Religion, 1998), pp. 132-134.

${ }^{38}$ Gordon Darnell Newby suggests the the classical doctrine of tahrif only emerged some years after the composition of Ibn Ishaq's sira: Newby, The Making of the Last Prophet, $\mathrm{p}$. 12. Tor Andrae mistakenly asserts: "When the Jews disputed his claim that the Arabian 


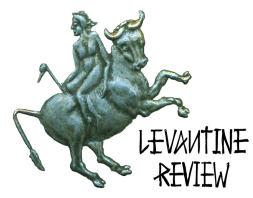

A final detail in Ibn Ishaq's discussion of Muhammad's policies vis-à-vis the Jews has to do with the famous jizya verse in the Koran, 9:29:

Fight those who do not believe in God and the last day and forbid not that which God and His apostle have forbidden and follow not the religion of truth from among those who have been given the scripture until they pay the poll tax out of hand being humbled... (p. 620).

Here Ibn Ishaq stresses two things. The first is that the revenue to be raised from the poll tax imposed on the people of the book is to compensate the Muslims for the funds lost by the exclusion of the polytheists from the pilgrimage to the Kaba in Mecca (as per Koran 9:28: "The polytheists are nothing but unclean, so let them not approach the sacred mosque after this year [...] If you fear poverty God will enrich you from His bounty"). As Ibn Ishaq puts it: "God gave them compensation for what He cut off from them in their former polytheism by way of what He gave them by way of poll tax from the people of scripture" (p. 620). The second point is that the imposition of the jizya is directly linked by Ibn Ishaq to the allegedly evil ways of the people of the scripture and their lies against God, as made plain by the Koran in the verses immediately following the jizya verse (9:30-3: "The Jews say Ezra is the son of God, while the Christians say the Messiah is the son of God. Such are their assertions, by which they imitate the infidels of old. God confound them! How perverse they are! [...]"). It is important to remind ourselves that in traditional Arab culture, honor is of central importance, and being forced "to buy protection from a more powerful tribe [...] seriously diminished one's honor." ${ }^{9}$ Ibn Ishaq thus suggests that the imposition of the jizya has both a practical purpose - the raising of revenue for the Muslims - and an ideological purpose, punishing and dishonoring the people of the book for their alleged religious perversity.

Ibn Ishaq later quotes Muhammad as setting the jizya at "one full dinar" and directing that Jews and Christians who paid the tax were "not to be turned" from their religion, and that those who paid the jizya were to have "the guarantee of God and His apostle," while those who withheld it were the enemies of God and His apostle (p. 643).

Prophet is mentioned in their sacred scriptures, he replied that their scriptures were corrupted." Tor Andrae, Mohammed: The Man and His Faith, p. 192. If Ibn Ishaq is to be believed, Muhammad made no such claim: instead, he accused the Jews of lying about what they knew to be in their (presumably reliable) scriptures. Andrae anachronistically reads the classical doctrine of tahrif back into the sirah, where it cannot be found.

${ }^{39}$ Raphael Patai, The Arab Mind (New York: Charles Scribner's Sons, 1973), p. 90. See also Philip Carl Salzman, Culture and Conflict in the Middle East (Humanity Books/Prometheus Books: Amherst NY: 2008), p. 106. 


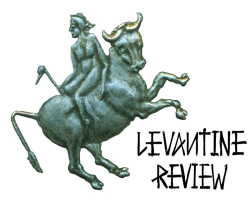

\section{MODERN ILLUSTRATIONS OF AN ANCIENT STEREOTYPE}

The negative depiction of Jews in the sira continues to influence Islamic discourse to the present day, as a few examples will illustrate.

- In his radio broadcasts for Nazi Germany, the founding father of the Palestinian Arab national movement, Hajj Amin al-Husseini, drew heavily on the Islamic tradition to craft his vicious anti-Semitic propaganda, telling his audience "Every Moslem knows that Jewish animosity to the Arabs dates back to the dawn of Islam. Every Moslem knows they opposed and hurt the prophet [...] So that the Koran says 'You shall find that the most hostile people are the Jews' [cf. Koran 5:82]." 40 As Jeffrey Herf observes, Hajj Amin al-Husseini's anti-Semitic propaganda was based almost entirely on Islamic sources, not on Nazi sources like Mein Kampf or the Protocols of the Elders of Zion. ${ }^{41}$

- A few years after the Second World War, one of the most important theoreticians of the Muslim Brotherhood, Sayyid Qutb, penned an essay entitled "Our Struggle Against the Jews" in which he traces the struggle back to the life of Muhammad: "Our community is concerned about Jewish deception and plotting: 'O People of the Book, Why do you wittingly cover the truth with falsehood and thereby hide the truth?' [cf. Koran 3:70-71] This is a characteristic of People of the Book, which Muslims must understand and take warning from: deception and plotting [...] The Jews began in this way from the first moment [... The Jews] replaced truth with falsehood in the whole [Islamic] heritage - except for [... the Qur'an] whose preservation Allah has guaranteed forever." ${ }^{42}$

- Dr. Muhammad Sayyed Tantawi held the most prestigious Sunni Muslim religious posts in Egypt as Grand Mufti (1986-1996) and as Grand Imam of AlAzhar Mosque and Grand Sheikh of Al-Azhar University (1996-2010). In 1969, Tantawi wrote a doctoral dissertation on the role of the Jews in Islamic history. In addition to repeating the Blood Libel (that Jews use the blood of murdered Gentiles to mix their matzoh bread) and the conspiracy theories of the Protocols of the Elders of Zion, Tantawi draws theme after theme from the Koran and the sira, alleging that "the Koran describes them [the Jews] as infidels and liars, as ungrateful, selfish, arrogant, and cowardly, as naggers and cheaters, rebels and lawbreakers [...] they violate treaties and agreements and act wrongly towards Allah; [...] they contemn the Koran and distort its words [...]"43 Tantawi also echoes Ibn Ishaq in several specific ways, e.g. by adopting Ibn Ishaq's interpretation of verses 3:113ff: "[The] Qur'an describes the Jews with their own

${ }^{40}$ Jeffery Herf, Nazi Propaganda for the Arab World, p. 153.

${ }^{41}$ Ibid., pp. 197, 213.

${ }^{42}$ Andrew G. Bostom ed., The Legacy of Islamic Anti-Semitism, p. 356.

${ }^{43}$ Middle East Media Research Center, Special Dispatch \#3108, July 20, 2010, http://www.memri.org/report/en/print4463.htm. 


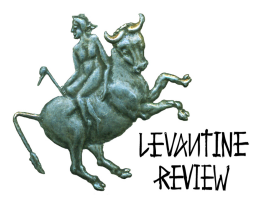

particular degenerate characteristics, i.e. killing the prophets of Allah, corrupting His words by putting them in the wrong places.... Only a minority of the Jews keep their word [... A]ll Jews are not the same. The good ones become Muslims, the bad ones do not (Qur'an 3:113)."44

- The leader of the Iranian Revolution of 1979, the Ayatollah Khomeini, in his 1970 "Program for the Establishment of an Islamic Government," asserted: "We see that the Jews (may God curse them) have meddled with the text of the Koran and have made certain changes in the Korans they have printed in the occupied territories. It is our duty to prevent this treacherous interference [... T] he Jews and their foreign backers are opposed to the very foundations of Islam..." 45

- Many Islamic preachers continue to refer to Jews as "brothers of apes and pigs," following both the Koran and the example set by Muhammad in addressing the Jews of the Banu Qurayza. ${ }^{46}$ For example, at a rally in the West Bank on Jan. 9, 2012, the Mufti of the Palestinian Authority, Sheikh Muhammad Hussein, was introduced by a Fatah speaker who proclaimed, "Our war with the descendants of apes and pigs [i.e. Jews] is a war of religion and faith." Far from distancing himself from this introduction, the Mufti went on to recite a hadith recounted by both Bukhari and Muslim in which Muhammad predicts the extermination of the Jews by the Muslims at the end of time. ${ }^{47}$ The talk was broadcast by the official Palestinian Authority television station. On Aug. 27, 2012, the Muslim Brotherhood website published an article by an Al-Azhar University lecturer and Muslim Brotherhood member, Hussein Shehata, in which he called upon "those who fast [during Ramadan...] to remember their brothers, those who wage jihad for the sake of Allah: in Palestine, against the Jews, the descendants of apes and

${ }^{44}$ Quoted in Andrew Bostom ed., The Legacy of Islamic Anti-Semitism, p. 33.

${ }^{45}$ Cited in Robert Wistrich, Anti-Semitism: The Longest Hatred, p. 219.

${ }^{46}$ See Menahem Milson, "Arab and Islamic Anti-Semitism," Middle East Media Research Institute Antisemitism Documentation Project, Inquiry and Analysis Series Report \#442, May 27, 2008, http://www.memri.org/report/en/0/0/0/0/0/0/2680.htm, and "Case Study: Portraying Jews and 'Apes and Pigs,'” Palestinian Media Watch, http://palwatch.org/main.aspx?fi=786. See also Middle East Media Research Institute Special Report \#11, Nov. 1, 2002; also on the same website, Special Dispatch Series \# 1217 (July 28, 2006) and \#1050 (Dec. 16, 2005). See also Neil J. Kressel, "The Sons of Pigs and Apes," pp. 26-33.

47 "Case Study: Portraying Jews and 'Apes and Pigs,"' Palestinian Media Watch, http://palwatch.org/main.aspx?fi=786. 


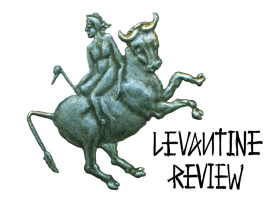

pigs..." ${ }^{48}$ In 2010, the current President of Egypt, Mohamed Morsi, referred to Jews as "descendants of apes and pigs." 49

\section{CONCLUSION}

Some authors, like Karen Armstrong, insist that Muhammad's conflict with the Jews was purely political, not religious or theological. ${ }^{50}$ Armstrong makes two related (and equally erroneous) assertions, that "Muhammad never asked them [the Jews] to accept his religion of al-Llah unless they particularly wished to convert" 51 and that "anti-Semitism is a vice of Western Christianity not of Islam." 52 Armstrong's approach is to mine the sira selectively for anything that can be used to place Muhammad in a favorable light for a modern Western audience, while ignoring or downplaying the less flattering portions of the narrative, especially as regards Muhammad's treatment of the Jews, but without explaining why the nicer parts of the sira should be considered more reliable than the less flattering ones. The same flawed approach can be found in recent apologetic works by high-profile Muslim authors like Omid Safi, ${ }^{53}$ Tariq Ramadan, ${ }^{54}$ and Reza Aslan. ${ }^{55}$

Certainly Muhammad's conflict with the Jews had political and military aspects. But Armstrong overlooks the evidence I have summarized here, which proves without a doubt that, according to the Islamic tradition, Muhammad's conflict with the Jews was above all religious or ideological, and that it included both a systematic defamation of the Jews that can only be described as anti-Semitic and substantial pressure on the Jews to convert to Islam. Whether historically accurate or not, Ibn Ishaq's narrative has a certain inner logic and plausibility to it. Muhammad claimed to be a prophet in the line of Abraham and Moses,

48 "Article on Muslim Brotherhood Website Praises Jihad Against America and the Jews 'The Descendants of Apes and Pigs,'” Middle East Media Research Institute, Special Dispatch \#4936, Sept. 7, 2012, http://www.memri.org/report/en/0/0/0/0/0/0/6656.htm.

${ }^{49}$ David D. Kirkpatrick, "Morsi's Slurs Against Jews Raise Doubts," The New York Times, Jan. 15, 2013, p. A1; also "Egyptian President Mohamed Morsi In 2010: No To Negotiations With The Blood-Sucking, Warmongering 'Descendants Of Apes And Pigs': Calls to Boycott U.S. Products," Middle East Media Research Institute, Jan. 4, 2013, Special Dispatch No. 5118, http://www.memri.org/report/en/print6909.htm.

${ }^{50}$ Karen Armstrong, Muhammad: A Biography of the Prophet (New York: HarperCollins, 1992), p. 185.

51 Ibid., p. 155.

52 Ibid., p. 209.

${ }^{53}$ Omid Safi, Memories of Muhammad: Why the Prophet Matters (New York: HarperCollins, 2009).

${ }^{54}$ Tariq Ramadan, In the Footsteps of the Prophet: Lessons from the Life of Muhammad (Oxford and New York: Oxford University Press, 2007).

${ }^{55}$ Reza Aslan, No god but God: The Origins, Evolution, and Future of Islam (New York: Random House, 2005). 


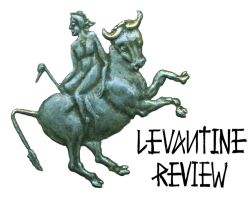

one whose coming was plainly foretold by the Torah, and it was clearly of vital importance to him that the Jews agree with his reading of the Torah. The rabbis of Medina asked embarrassing questions and pressed Muhammad on his theological claims. They denied that the Torah foretold his coming as a prophet, and they denied that an Arab could be a prophet in the Jewish tradition (pp. 239, 257). After the move to Medina in 622, Muhammad was at war with the pagan Quraysh of Mecca. His authority as a political and military leader, and thus his survival, depended on his followers accepting him as a prophet receiving authentic divine revelations. The Jews, due to the moral weight of the Hebrew Bible and the literacy of their rabbis, thus posed the single-greatest ideological threat to Muhammad and the nascent Islamic state. ${ }^{56}$ According to Ibn Ishaq, he worked to discredit them by repeatedly calling them liars whose claims about their own scriptures were not to be trusted. Finally, he found reasons to crush them militarily and, at the end of his life, to order their expulsion (along with other non-Muslims) from the Arabian peninsula (pp. 523, 525,689 ). Ibn Ishaq's sira, echoing large portions of the Koran, leaves the reader with the distinct impression that any Jew who reads the Torah and refuses to convert to Islam is ipso facto a liar, and that the defining mark of Jews who refuse to convert to Islam is treachery, infidelity, and dishonesty. Surely this is one of the deepest roots of the antiJewish prejudice that persists to this day in Islamic societies.

After the Nazi Holocaust, many Christians began a serious effort to understand and overcome the awful legacy of Christian anti-Semitism. This effort included a re-examination and re-interpretation of the foundational documents of the Christian tradition, including the canonical Gospels themselves. ${ }^{57}$ It is time for Muslims to subject their own tradition to

56 Thus W. Montgomery Watt: "The most important aspect of the break with the Jews was the intellectual. The Jews were attacking the whole set of ideas on which Muhammad's position was based. They declared that some of the things in the Qur'an contradicted the ancient scriptures in their hands, and must therefore be false; in that case they could not be a revelation and Muhammad could not be a prophet. This was very serious. If many of the Muslims thought that what the Jews were saying was true, the whole structure of the community so carefully built by Muhammad would crumble away... [Muhammad] needed the support of men who whole-heartedly believed in the religious aspect of his mission. The Jews were doing what they could to deprive him of such support, and as possessors of the scriptures they were able to act effectively." W. Montgomery Watt, Muhammad: Prophet and Statesman, pp. 114-115.

57 See, for example, Roman Catholic Archbishop Joseph Cardinal Bernardin's 1995 Hebrew University lecture, “Antisemitism: The Historical Legacy and Challenge for Christians," in Thomas A. Baima ed., A Legacy of Catholic-Jewish Dialogue: The Joseph Cardinal Bernardin Lectures (Chicago: Liturgy Training Publications, 2012), pp. 1-19. On the removal of antiSemitic language from Roman Catholic religious education materials, see Robert D. McFadden, "Sister Rose Thering, Nun Dedicated to Bridging Gap with Judaism, Dies at 85," The New York Times, May 8, 2006, p. A21. 
Spoerl / The Levantine Review Volume 2 Number 1 (Spring 2013)

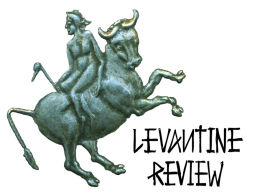

the same critical scrutiny. They are hindered, not helped, in this effort by "politically correct" Western writers like Karen Armstrong who distort the historical record by insisting falsely that anti-Semitism is a purely Christian disease with no roots in the Islamic tradition. 


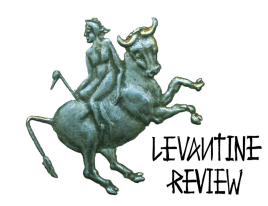

\begin{abstract}
APPENDIX
Koranic Verses that Accuse the Jews of Dishonesty Vis-à-vis Their own Scriptures ${ }^{58}$
\end{abstract}

2:59 "But that which they were told the wrongdoers replaced with other words..."

2:75 "Do you then hope that they will believe in you, when some of them have already heard the Word of God and knowingly perverted it, although they understood its meaning?"

2:79 "Woe betide those that write the scriptures with their own hands and then declare: 'This is from God,' in order to gain some paltry end."

2:89 "And now that a Book confirming their own has come to them from God, they deny it, although they know it to be the truth..."

2:101 "And now that an apostle has come to them from God confirming their own Scriptures, some of those to whom the Scriptures have been given cast off the Book of God over their backs as though they know nothing..."

2:140 "Who is more wicked than the man who hides a testimony he has received from God?"

2:146 "Those to whom We gave the Scriptures know Our apostle as they know their own sons. But some of them deliberately conceal the truth."

2:159-160 "Those that hide the clear proofs and the guidance We have revealed after We had proclaimed them in the Scriptures shall be cursed by God and cursed by those who invoke damnation; except those that repent and mend their ways and make known the truth."

2:174 "Those that suppress any part of the Scriptures which God has revealed in order to gain some paltry end shall swallow nothing but fire into their bellies."

2:211 "Ask the Israelites how many conspicuous signs We gave them. He that tampers with the gift of God after it is bestowed on him shall find that God is stern in retribution."

3:70-71 "People of the Book! Why do you deny God's revelations when you know that they are true? People of the Book! Why do you confound the true with the false, and knowingly hide the truth?"

3:78 "And there are some among them who twist their tongues when quoting the Scriptures so that you may think it from the Scriptures, whereas it is not from the

${ }^{58}$ From The Koran, trans. N.J. Dawood (London: Penguin Books, 1999). 


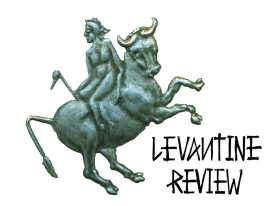

Scriptures. They say: 'This is from God,' whereas it is not from God. Thus they knowingly ascribe falsehood to God."

3:187 "When God made a covenant with those to whom the Scriptures were given He said: 'Proclaim these to mankind and do not suppress them.' But they cast the Scriptures over their backs and sold them for a paltry price."

5:12-14 "God made a covenant with the Israelites... But because they broke their covenant We laid on them our curse and hardened their hearts. They have tampered with words out of their context and forgotten much of what they were enjoined. You will ever find them deceitful, except for a few of them."

5:15 "People of the Book! Our apostle has come to reveal to you much of what you have hidden of the Scriptures..."

5:41 "They tamper with words out of their context..."

6:91 "Say: 'Who, then, revealed the Scriptures which Moses brought down, a light and a guide for mankind? You have transcribed them on scraps of paper, declaring some and suppressing much..."

13:36 "Those to whom We gave the Scriptures rejoice in what is revealed to you, while some factions deny a part of it."

* Joseph S. Spoerl is Professor in the Philosophy Department at Saint Anselm College in Manchester , NH. He holds BA and MA degrees from Boston University, and MA and Ph.D degrees from the University of Toronto. He has published in such journals as Comparative Islamic Studies, The Journal of Conflict Studies, the Journal for the Study of Antisemitism, and the American Journal of Jurisprudence. 